"Mircea cel Batran" Naval Academy Scientific Bulletin, Volume XIX - 2016 - Issue 2 The journal is indexed in: PROQUEST / DOAJ / Crossref / EBSCOhost / INDEX COPERNICUS / DRJI / OAJI I JOURNAL INDEX / I2OR / SCIENCE LIBRARY INDEX / Google Scholar / Academic Keys/ ROAD Open Access I Academic Resources / Scientific Indexing Services / SCIPIO / JIFACTOR

\title{
CONSIDERATIONS REGARDING THE STRUCTURAL RESPONSE OF A 10000X500X100MM PILE DURING PILE DRIVING WITH A 450KG RAM, FALLING FROM 1M HEIGHT
}

\author{
lonut - Dragos NEAGU ${ }^{1}$ \\ Adrian POPA ${ }^{2}$ \\ Beazit ALI ${ }^{3}$ \\ Levent ALI ${ }^{4}$
}

${ }^{1}$ PhDcEngManaging Director - Engineering \& Fabrication, Marine and Offshore Consultants

${ }^{2}$ Assist prof. PhD Eng. "Mircea cel Batran" Naval Academy

${ }^{3}$ Professor PhD Eng. "Mircea cel Batran" Naval Academy

${ }^{4}$ PhDcEng, Bureau Veritas, Romania

Abstract: Piles are used when the building soil don't have enough strength cu support the structure. One of the pilling methods is to drive the pile. In fact, a vertical pile is hit with a ram. This method is a very good one, because the soil around the pile is compressed and the structure bed is strengthened that way. The negative aspect of this method is the pile is solicited in other ways than it was design.

In this paper are presented the results of a dynamic FEM analysis for a $10000 \times 500 \times 100 \mathrm{~mm}$ pile when it is hit by a $450 \mathrm{~kg}$ ram, falling from $1 \mathrm{~m}$ height.

Keywords: FEM, Structural analysis, pile driving

Piles are used when the building soil don't have enough strength cu support the structure.

One of the pilling methods is to drive the pile. In fact, a vertical pile is hit with a ram. This method is a very good one, because the soil around the pile is compressed and the structure bed is strengthened that way. The negative aspect of this method is the pile is solicited in other ways than it was design.

A standard operation of pile driving is presented in below picture.

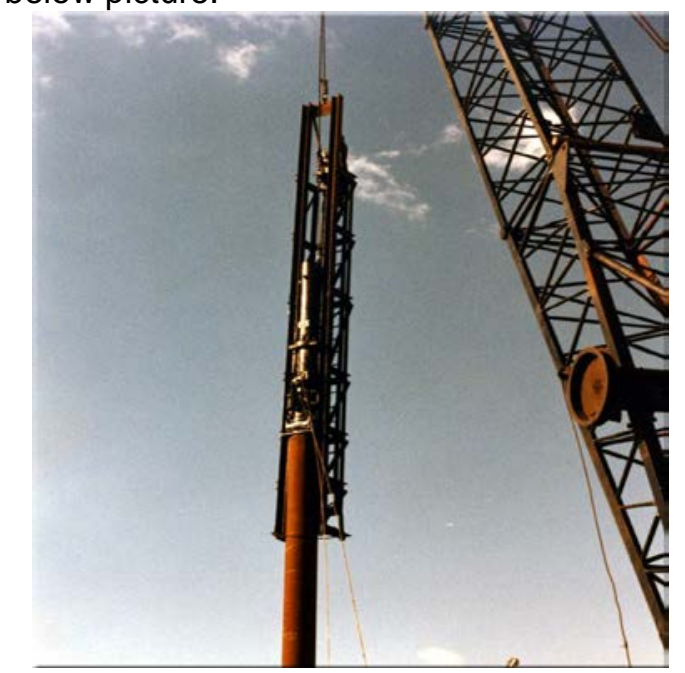

Figure 1 A standard pile driving operations (www.vulcanhammer.info)

For pilling operations, piles are structural checked for this kind of operation.
This paperwork presents an analysis of the structural response for a $10000 \times 500 \times 100 \mathrm{~mm}$ pile when is driven with a $450 \mathrm{~kg}$ ram who falls from 1 $\mathrm{m}$ height. For the analysis was used Ansys 12.1 software.

The pile and the ram were modeled like in below figure:

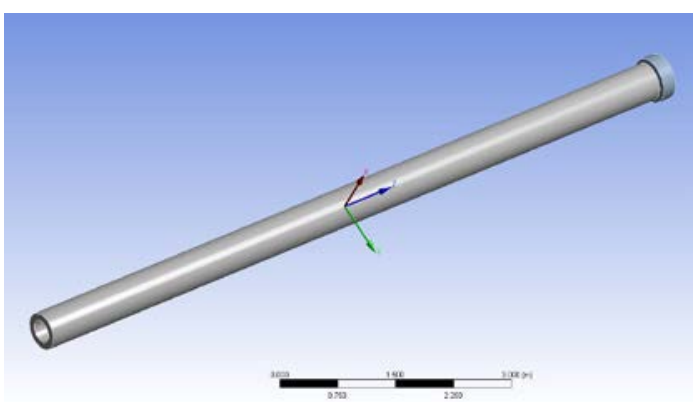

Figure 2 The model of the pile and ram, at the impact moment

The mesh consists in 10260 nods and 5103 elements:

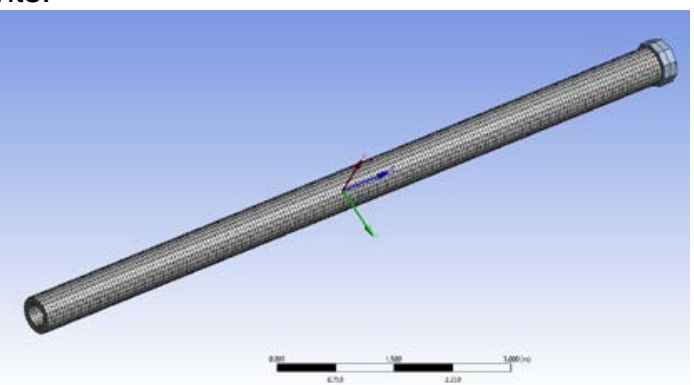

Figure 3The mesh structure 
"Mircea cel Batran" Naval Academy Scientific Bulletin, Volume XIX - 2016 - Issue 2

The journal is indexed in: PROQUEST / DOAJ / Crossref / EBSCOhost / INDEX COPERNICUS / DRJI / OAJI / JOURNAL INDEX I I2OR / SCIENCE LIBRARY INDEX / Google Scholar / Academic Keys/ ROAD Open Access I Academic Resources / Scientific Indexing Services / SCIPIO / JIFACTOR

The pile was considered to be fixed at the base, and the ram hits the top with $4.429 \mathrm{~m} / \mathrm{s}$ impact speed. This speed corresponds with the impact speed after $1 \mathrm{~m}$ fall.

For studying the structural response we considered the von Mises tensions.

The study was carried out as a dynamic one for one second, in 101 steps:

Table 1: Analysis steps

\begin{tabular}{|r|r|r|r|}
\hline Step & Time & Step & Time \\
\hline 1 & 0.00 & 21 & 0.20 \\
\hline 2 & 0.01 & 22 & 0.21 \\
\hline 3 & 0.02 & 23 & 0.22 \\
\hline 4 & 0.03 & 24 & 0.23 \\
\hline 5 & 0.04 & 25 & 0.24 \\
\hline 6 & 0.05 & 26 & 0.25 \\
\hline 7 & 0.06 & 27 & 0.26 \\
\hline 8 & 0.07 & 28 & 0.27 \\
\hline 9 & 0.08 & 29 & 0.28 \\
\hline 10 & 0.09 & 30 & 0.29 \\
\hline 11 & 0.10 & 31 & 0.30 \\
\hline 12 & 0.11 & 32 & 0.31 \\
\hline 13 & 0.12 & 33 & 0.32 \\
\hline 14 & 0.13 & 34 & 0.33 \\
\hline 15 & 0.14 & 35 & 0.34 \\
\hline 16 & 0.15 & 36 & 0.35 \\
\hline 17 & 0.16 & 37 & 0.36 \\
\hline 18 & 0.17 & 38 & 0.37 \\
\hline 19 & 0.18 & 39 & 0.38 \\
\hline 20 & 0.19 & 40 & 0.39 \\
\hline
\end{tabular}

\begin{tabular}{|l|l|l|l|}
\hline 41 & 0.40 & 61 & 0.60 \\
\hline 42 & 0.41 & 62 & 0.61 \\
\hline 43 & 0.42 & 63 & 0.62 \\
\hline 44 & 0.43 & 64 & 0.63 \\
\hline 45 & 0.44 & 65 & 0.64 \\
\hline 46 & 0.45 & 66 & 0.65 \\
\hline 47 & 0.46 & 67 & 0.66 \\
\hline 48 & 0.47 & 68 & 0.67 \\
\hline 49 & 0.48 & 69 & 0.68 \\
\hline 50 & 0.49 & 70 & 0.69 \\
\hline 51 & 0.50 & 71 & 0.70 \\
\hline 52 & 0.51 & 72 & 0.71 \\
\hline 53 & 0.52 & 73 & 0.72 \\
\hline 54 & 0.53 & 74 & 0.73 \\
\hline
\end{tabular}

DOI: 10.21279/1454-864X-16-12-036

The minimum value of the von Mises stress for each step is presented below:

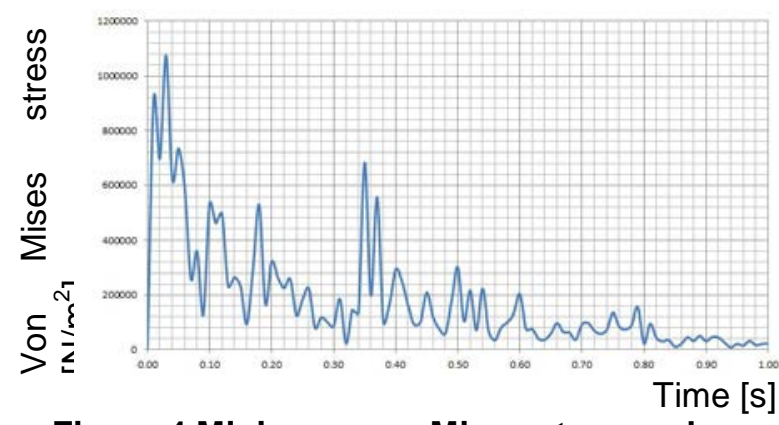

Figure 4 Minimum von Mises stress value variation

The maximum value of the von Mises stress for each step is presented below: 
"Mircea cel Batran" Naval Academy Scientific Bulletin, Volume XIX - 2016 - Issue 2

The journal is indexed in: PROQUEST / DOAJ / Crossref / EBSCOhost / INDEX COPERNICUS / DRJI / OAJI / JOURNAL INDEX / I2OR / SCIENCE LIBRARY INDEX / Google Scholar / Academic Keys/ ROAD Open Access I Academic Resources / Scientific Indexing Services / SCIPIO / JIFACTOR

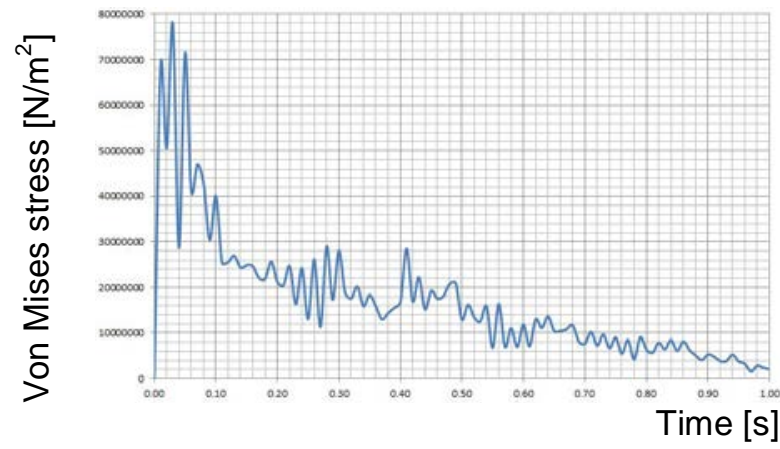

Figure 5 Maximum von Mises stress valuevariation

Repartition diagram of the equivalent stress after the impact are presented as follows:

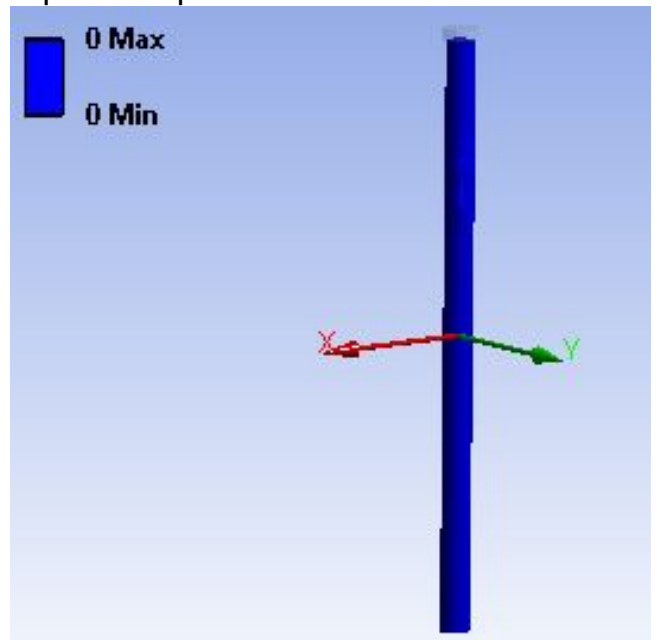

Figure 6 Von Misses stress diagram for step 1

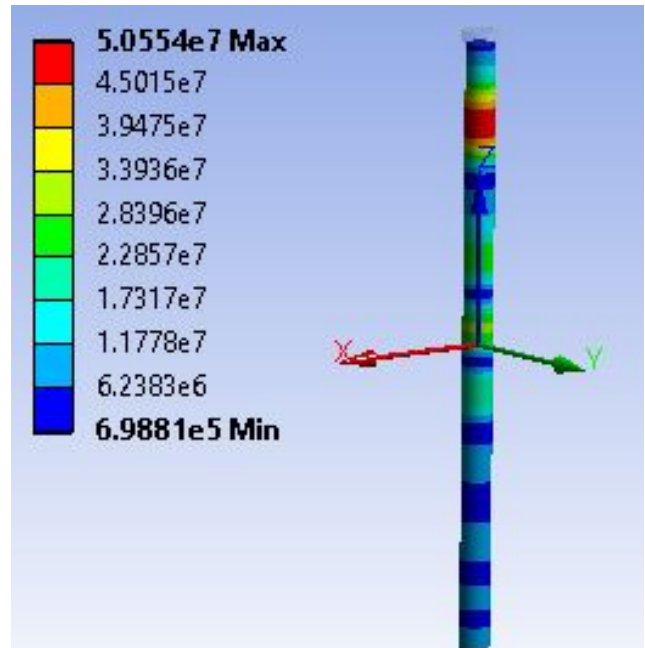

Figure 7 Von Misses stress diagram for step 3

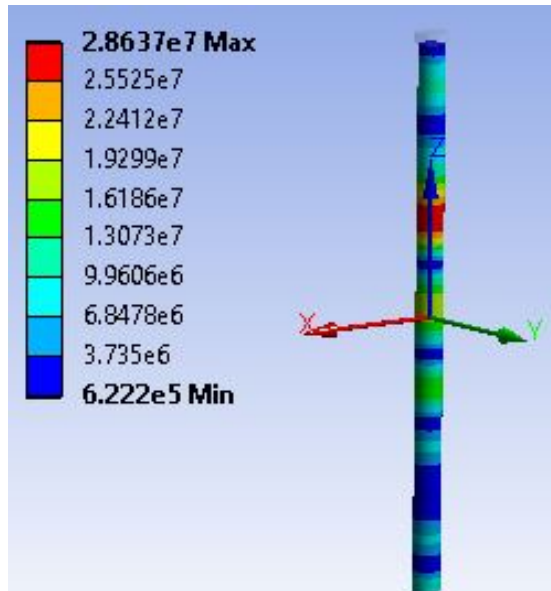

Figure 8 Von Misses stress diagram for step 5

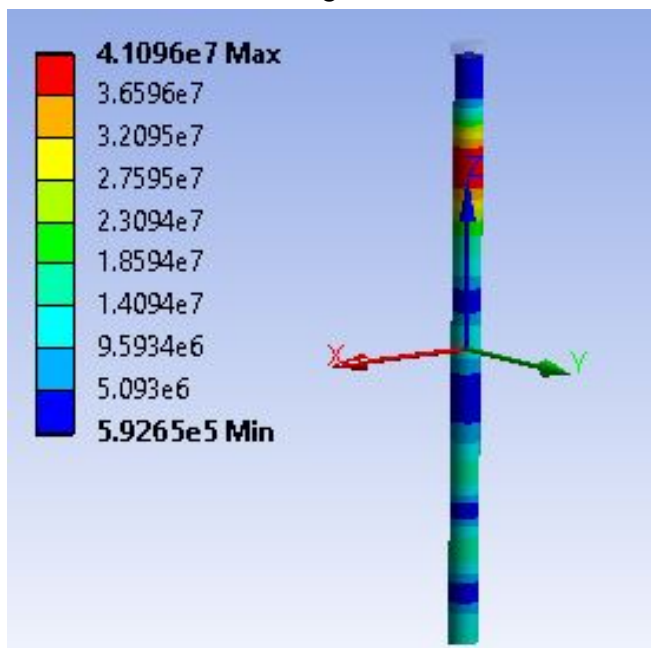

Figure 9 Von Misses stress diagram for step 7

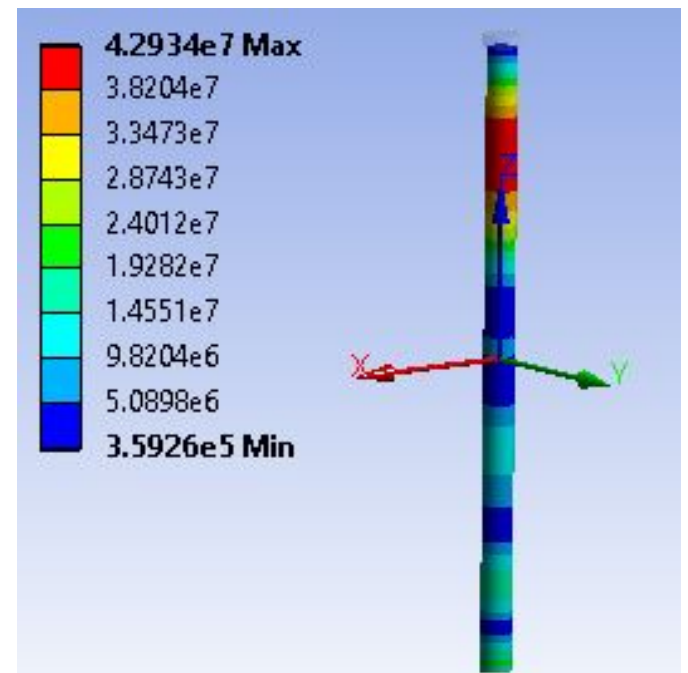

Figure 10 Von Misses stress diagram for step 9 
"Mircea cel Batran" Naval Academy Scientific Bulletin, Volume XIX - 2016 - Issue 2

The journal is indexed in: PROQUEST / DOAJ / Crossref / EBSCOhost / INDEX COPERNICUS / DRJI / OAJI / JOURNAL INDEX I I2OR / SCIENCE LIBRARY INDEX / Google Scholar / Academic Keys/ ROAD Open Access I Academic Resources / Scientific Indexing Services / SCIPIO / JIFACTOR

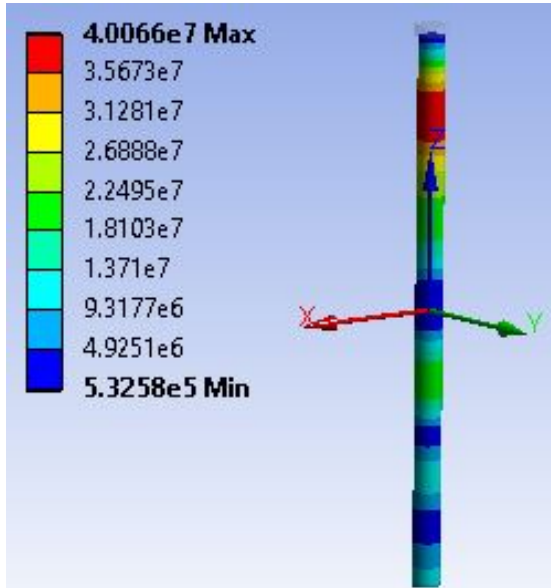

Figure 11 Von Misses stress diagram for step 11

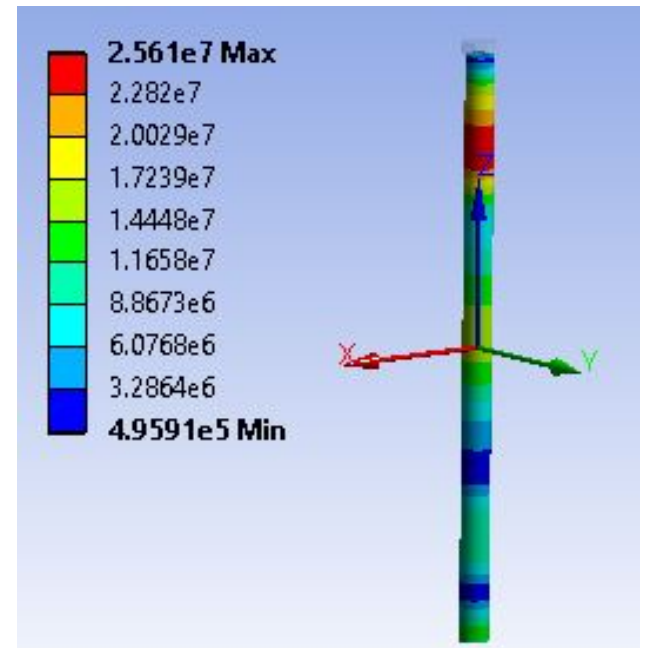

Figure 12 Von Misses stress diagram for step 13

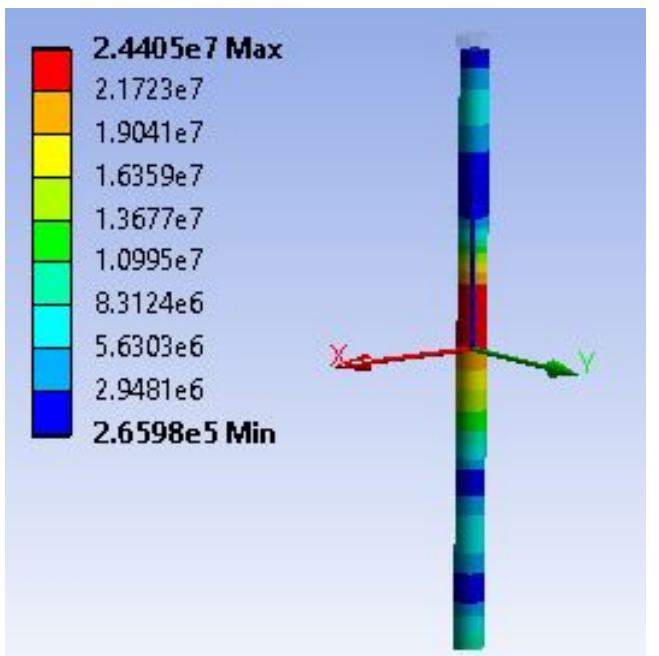

Figure 13 Von Misses stress diagram for step 15

DOI: 10.21279/1454-864X-16-12-036

(c) 2015. This work is licensed under the Creative Commons Attribution-Noncommercial-Share Alike 4.0 License.
Figure 14 Von Misses stress diagram for step 17

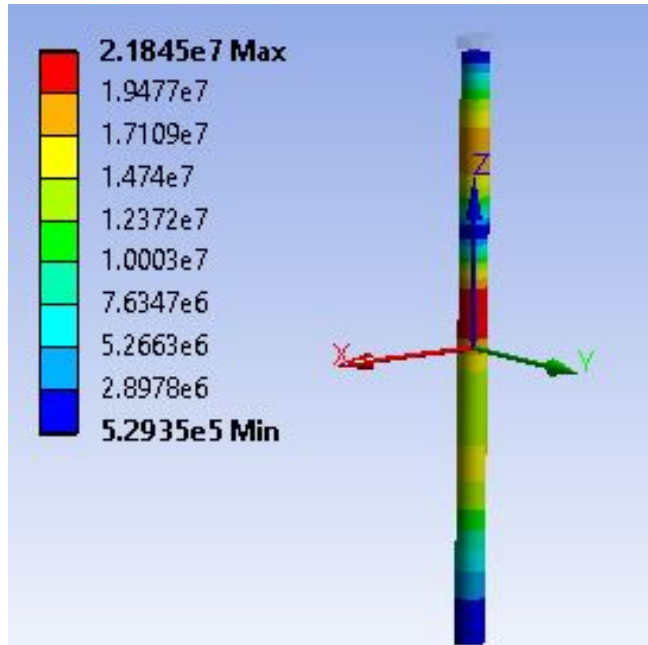

Figure 15 Von Misses stress diagram for step 19

Figure 16 Von Misses stress diagram for step 21

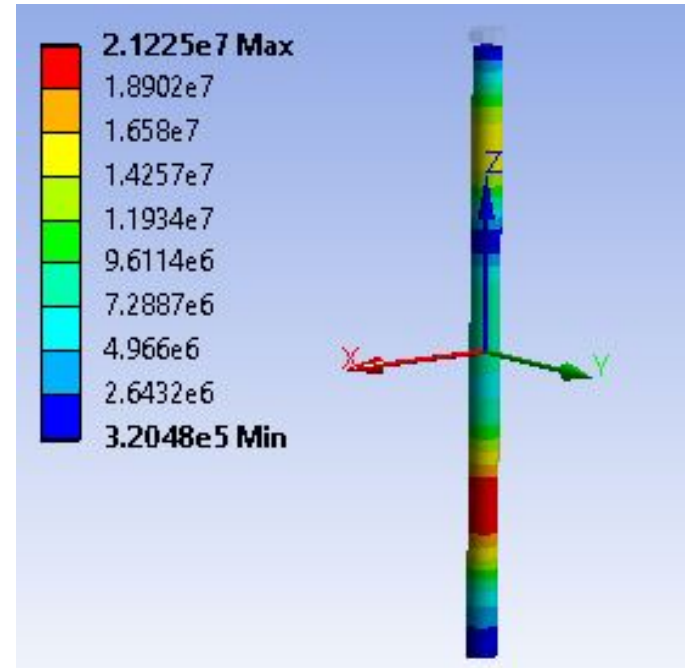


"Mircea cel Batran" Naval Academy Scientific Bulletin, Volume XIX - 2016 - Issue 2

The journal is indexed in: PROQUEST I DOAJ / Crossref / EBSCOhost / INDEX COPERNICUS / DRJI / OAJI I JOURNAL INDEX / I2OR / SCIENCE LIBRARY INDEX / Google Scholar / Academic Keys/ ROAD Open Access I Academic Resources / Scientific Indexing Services / SCIPIO / JIFACTOR

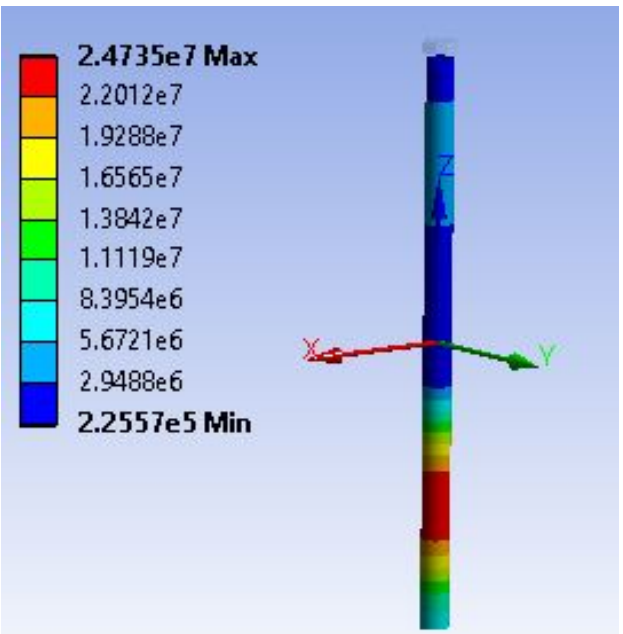

Figure 17 Von Misses stress diagram for step 23

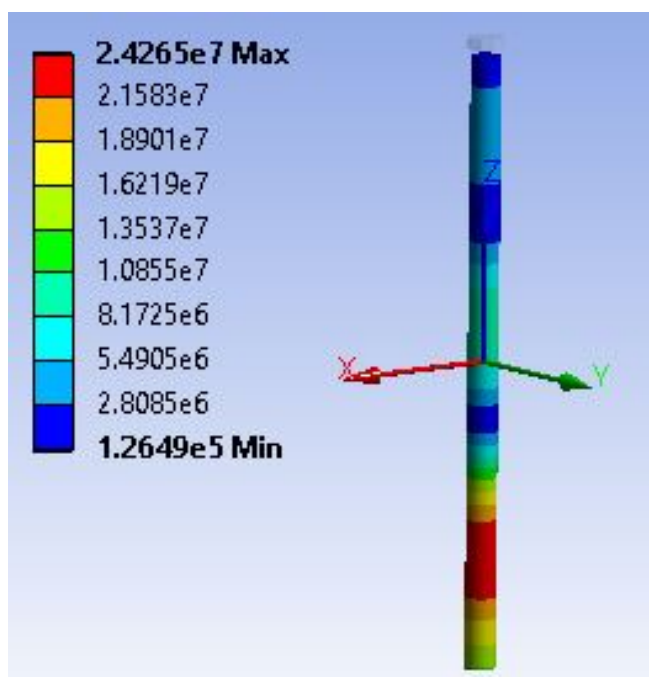

Figure 18 Von Misses stress diagram for step 25

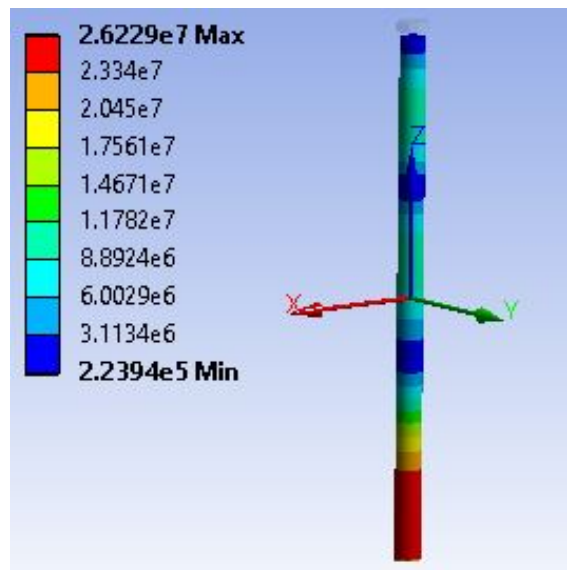

Figure 19 Von Misses stress diagram for step 27

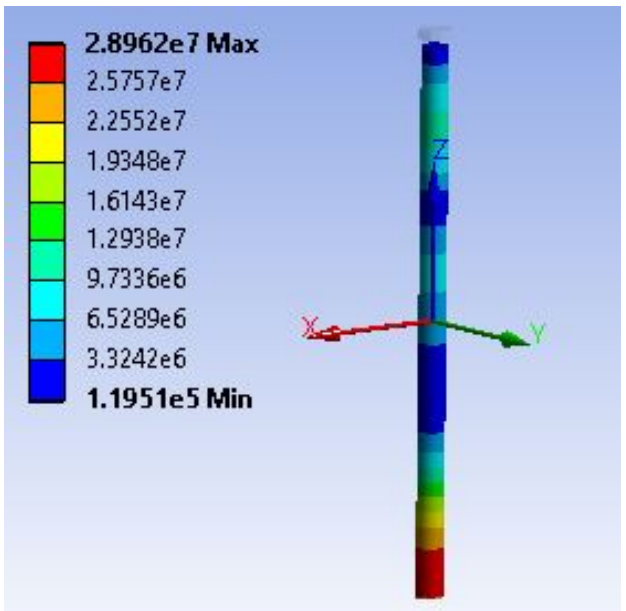

Figure 20 Von Misses stress diagram for step 29

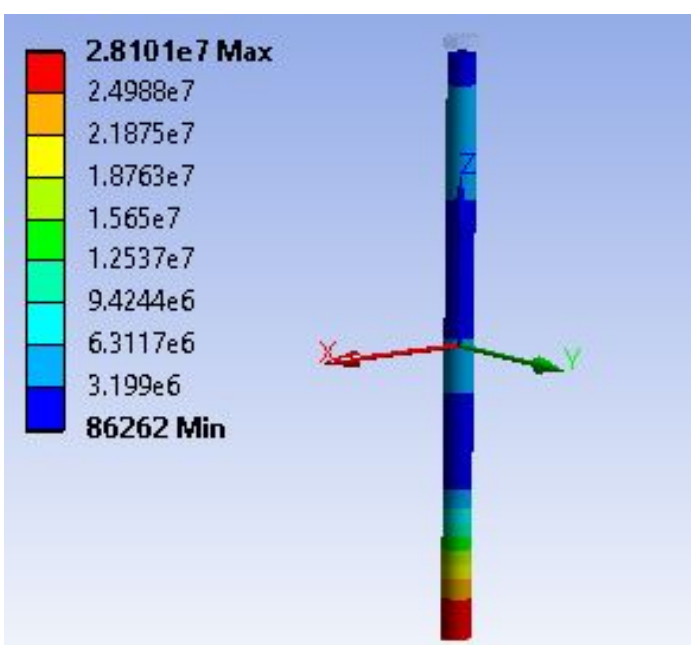

Figure 21 Von Misses stress diagram for step 31

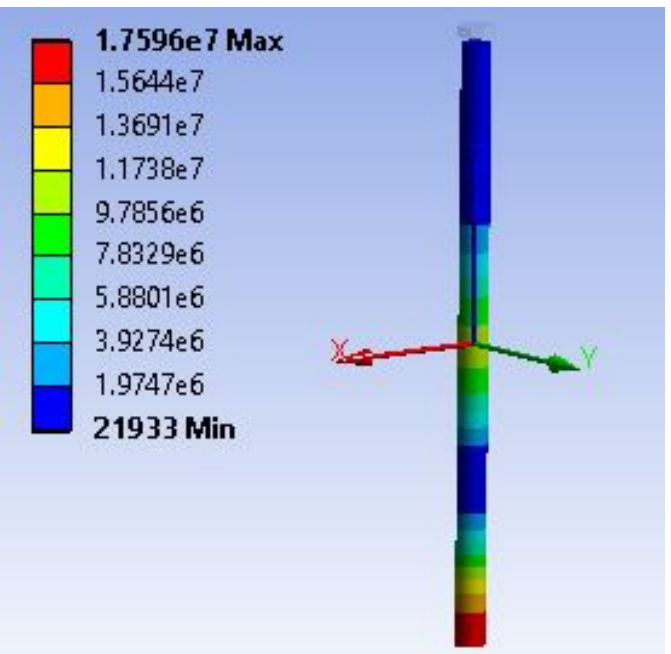

Figure 22 Von Misses stress diagram for step 33

(c) 2015. This work is licensed under the Creative Commons Attribution-Noncommercial-Share Alike 4.0 License. 
"Mircea cel Batran" Naval Academy Scientific Bulletin, Volume XIX - 2016 - Issue 2

The journal is indexed in: PROQUEST / DOAJ / Crossref / EBSCOhost / INDEX COPERNICUS / DRJI / OAJI / JOURNAL INDEX I I2OR / SCIENCE LIBRARY INDEX / Google Scholar / Academic Keys/ ROAD Open Access I Academic Resources / Scientific Indexing Services / SCIPIO I JIFACTOR

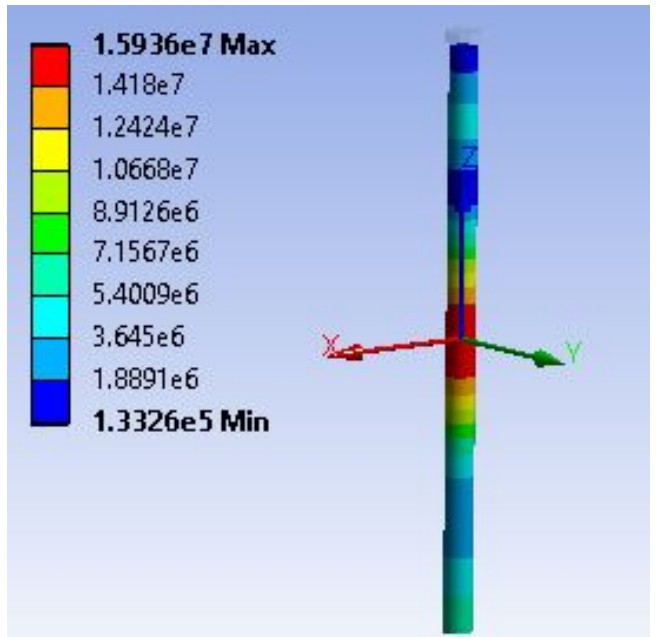

Figure 23 Von Misses stress diagram for step 35

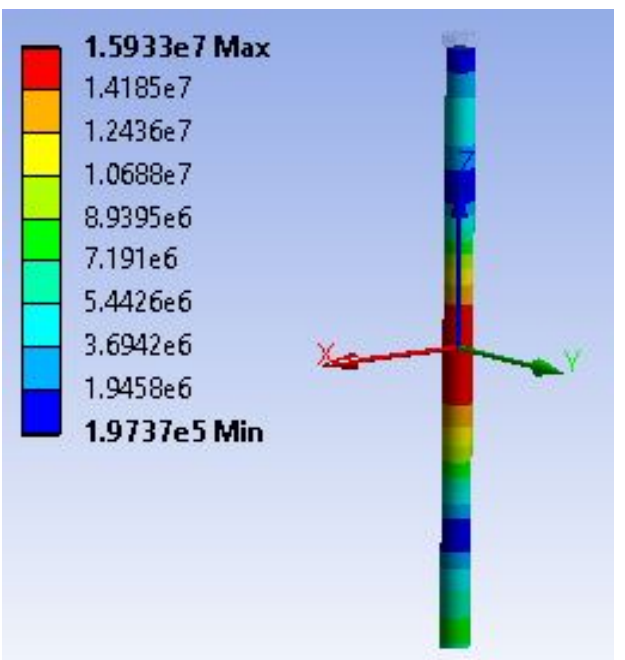

Figure 24 Von Misses stress diagram for step 37

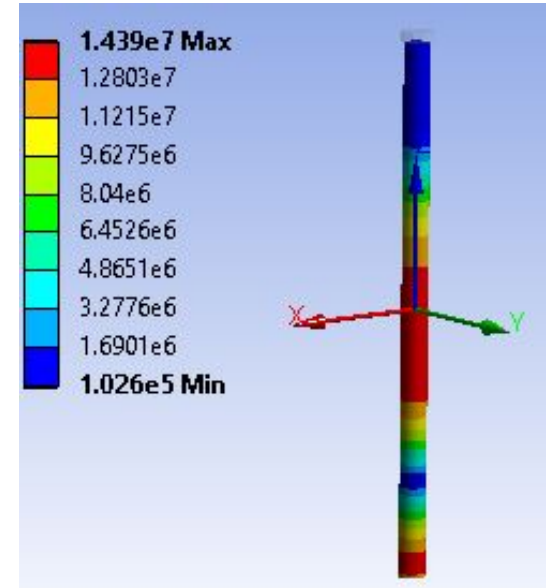

Figure 25 Von Misses stress diagram for step 39

DOI: 10.21279/1454-864X-16-12-036

(c) 2015. This work is licensed under the Creative Commons Attribution-Noncommercial-Share Alike 4.0 License.

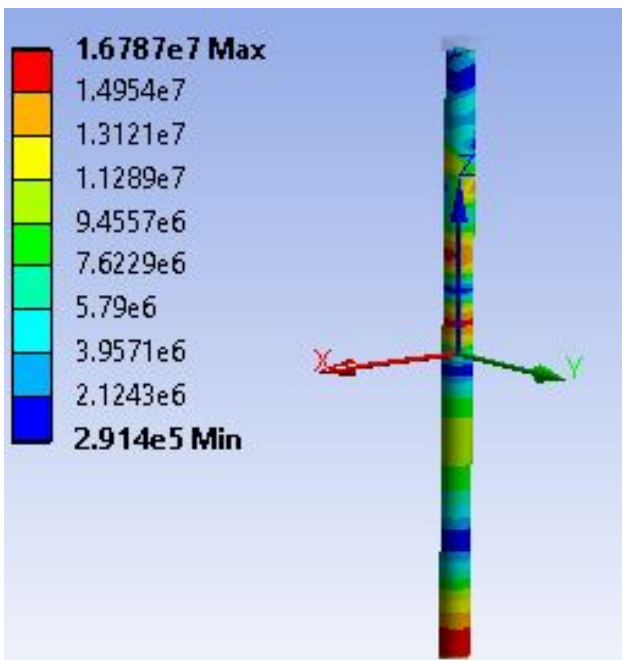

Figure 26 Von Misses stress diagram for step 41

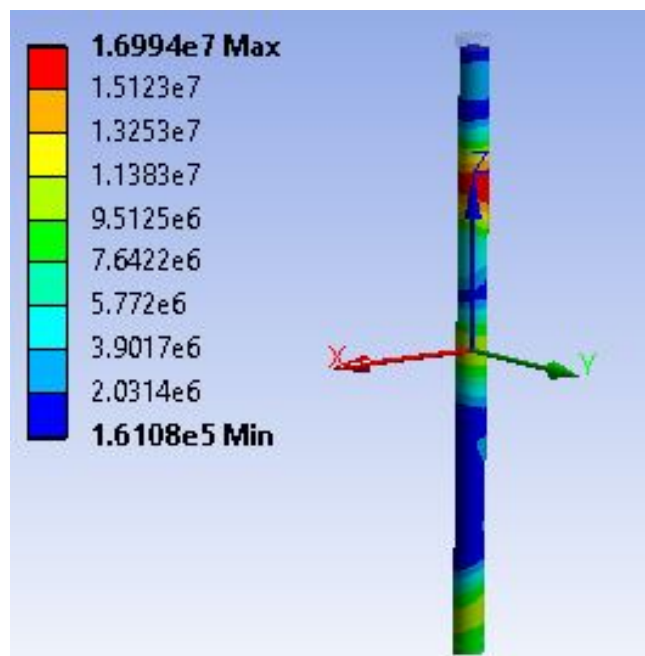

Figure 27 Von Misses stress diagram for step 43

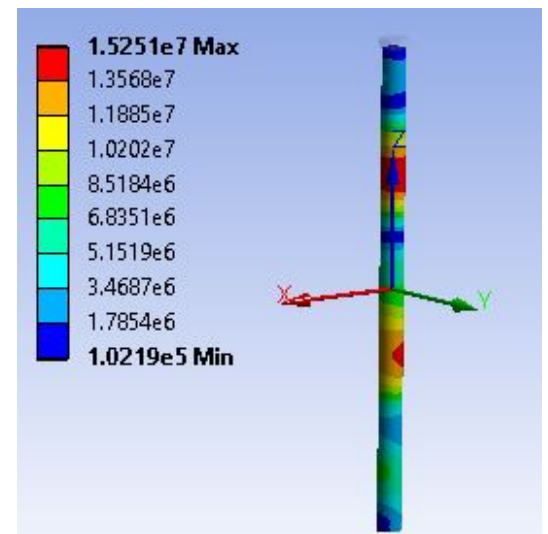

Figure 28 Von Misses stress diagram for step 45 
"Mircea cel Batran" Naval Academy Scientific Bulletin, Volume XIX - 2016 - Issue 2 The journal is indexed in: PROQUEST I DOAJ / Crossref / EBSCOhost / INDEX COPERNICUS / DRJI / OAJI I JOURNAL INDEX / I2OR / SCIENCE LIBRARY INDEX / Google Scholar / Academic Keys/ ROAD Open Access I Academic Resources / Scientific Indexing Services / SCIPIO / JIFACTOR

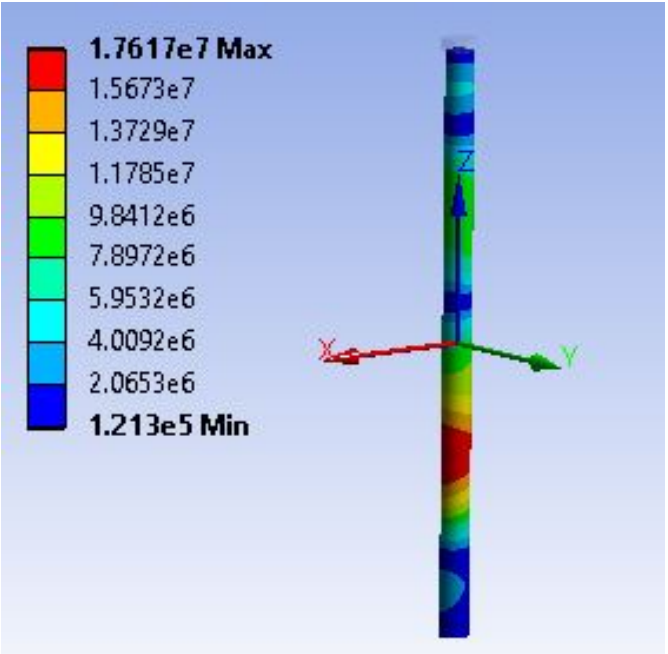

Figure 29 Von Misses stress diagram for step 47

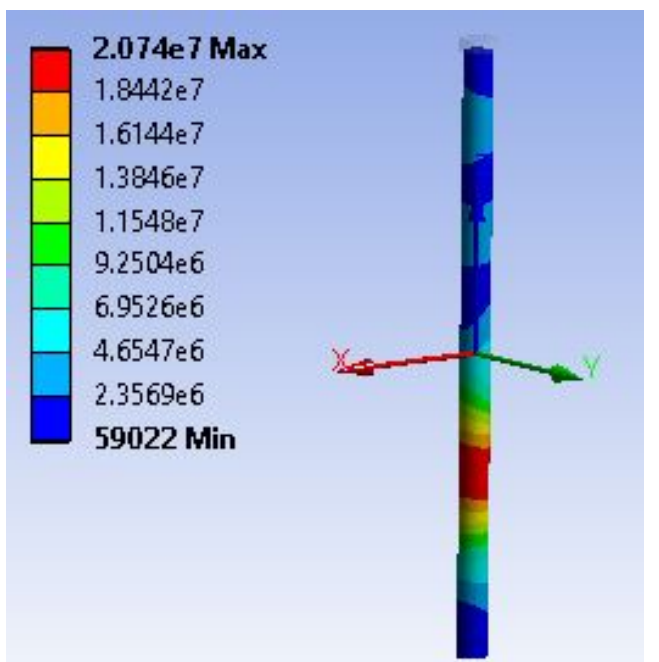

Figure 30 Von Misses stress diagram for step 49

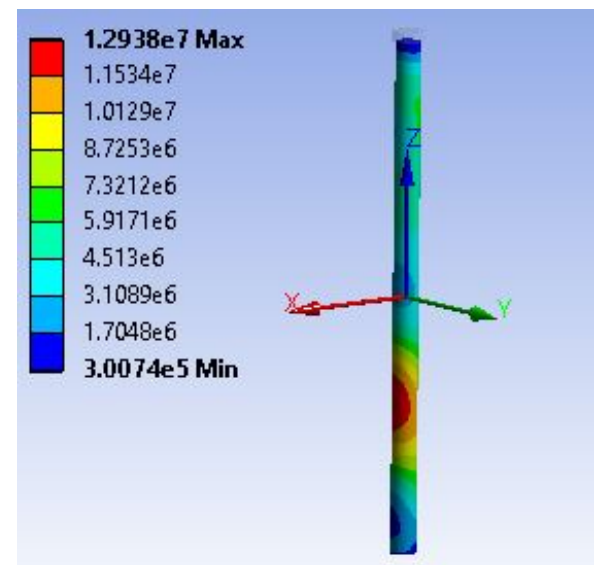

Figure 31 Von Misses stress diagram for step 51

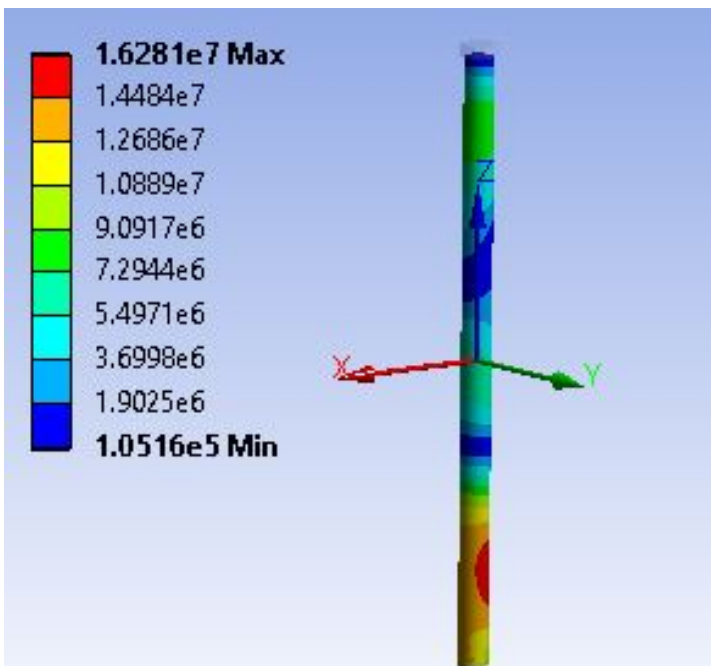

Figure 32 Von Misses stress diagram for step 53

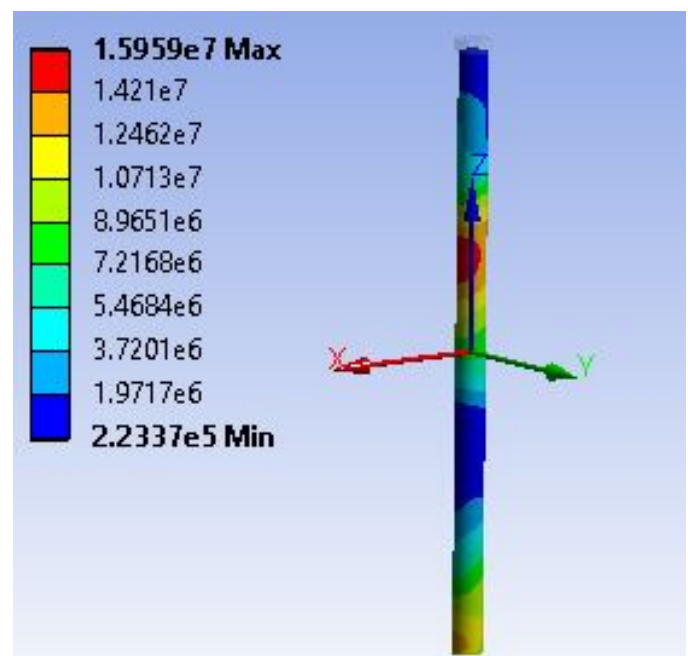

Figure 33 Von Misses stress diagram for step 55

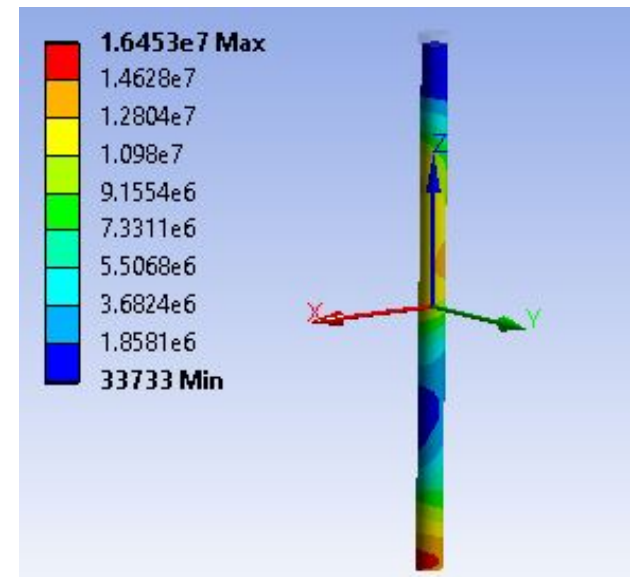

Figure 34 Von Misses stress diagram for step 57 
"Mircea cel Batran" Naval Academy Scientific Bulletin, Volume XIX - 2016 - Issue 2

The journal is indexed in: PROQUEST / DOAJ / Crossref / EBSCOhost / INDEX COPERNICUS / DRJI / OAJI / JOURNAL INDEX I I2OR / SCIENCE LIBRARY INDEX I Google Scholar / Academic Keys/ ROAD Open Access I Academic Resources / Scientific Indexing Services / SCIPIO I JIFACTOR

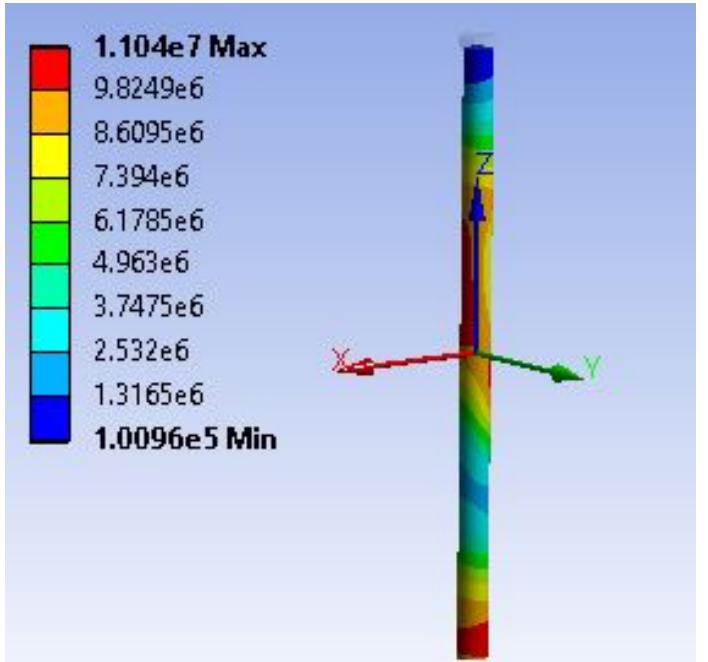

Figure 35 Von Misses stress diagram for step 59

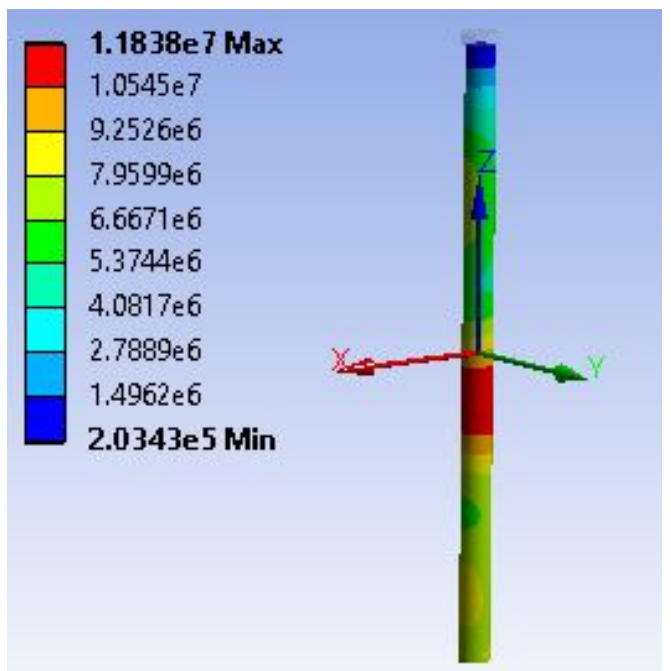

Figure 36 Von Misses stress diagram for step 61

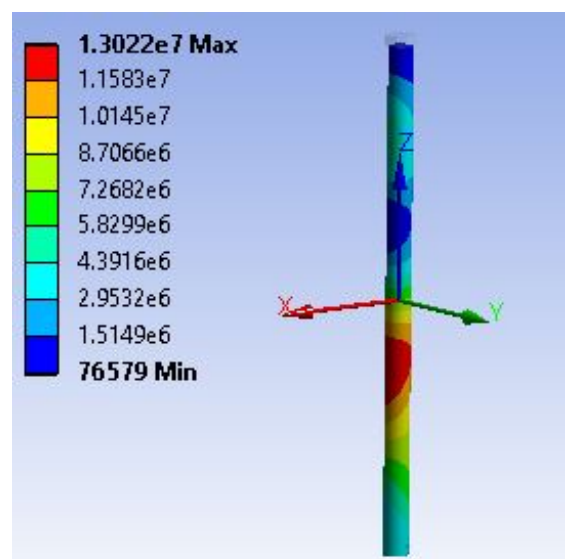

Figure 37 Von Misses stress diagram for step 63

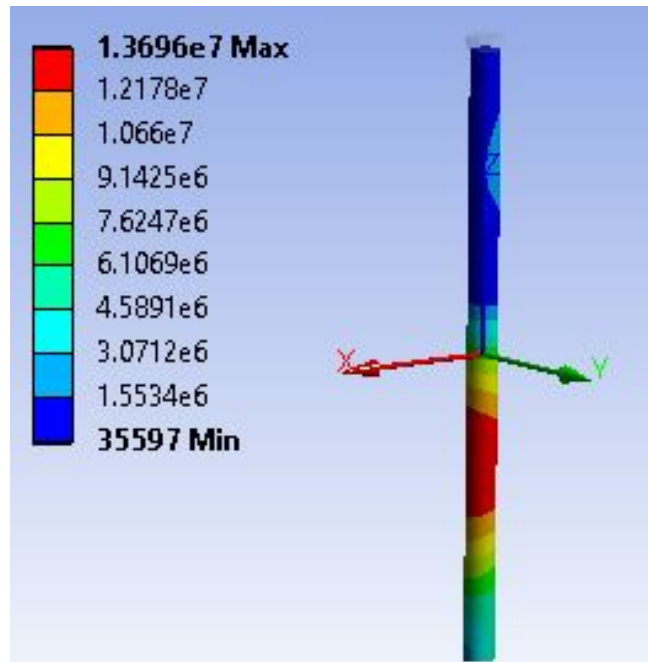

Figure 38 Von Misses stress diagram for step 65

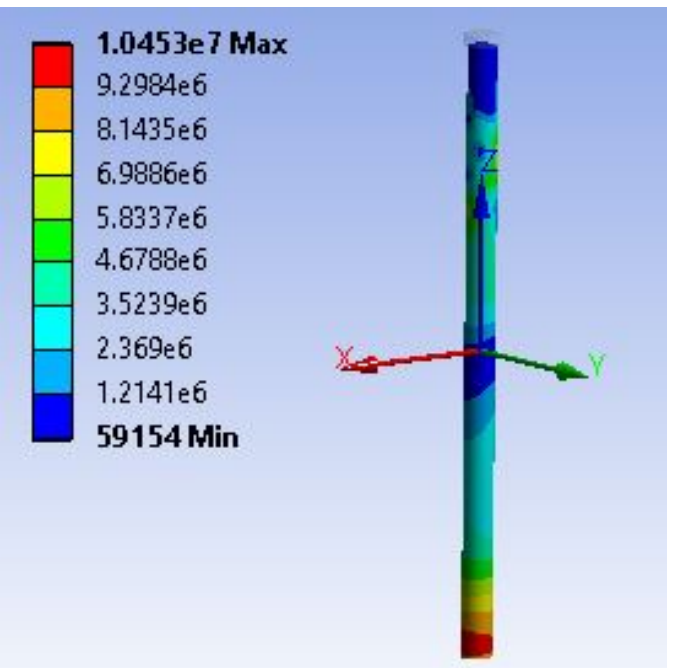

Figure 39 Von Misses stress diagram for step 67

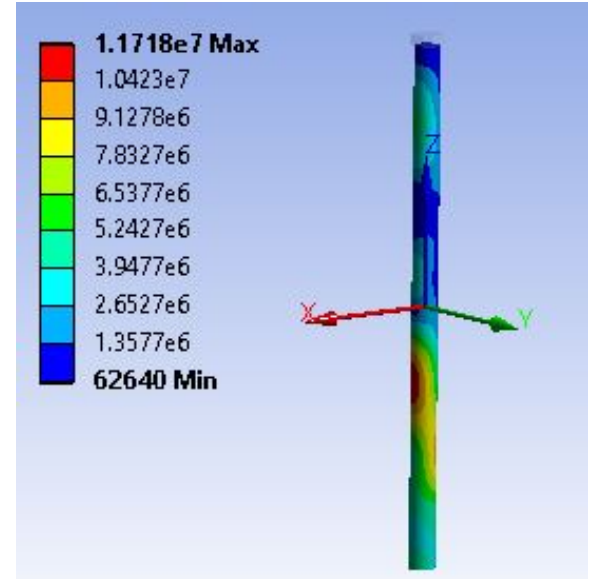

Figure 40 Von Misses stress diagram for step 69 
"Mircea cel Batran" Naval Academy Scientific Bulletin, Volume XIX - 2016 - Issue 2

The journal is indexed in: PROQUEST / DOAJ / Crossref / EBSCOhost / INDEX COPERNICUS / DRJI / OAJI / JOURNAL INDEX I I2OR / SCIENCE LIBRARY INDEX I Google Scholar / Academic Keys/ ROAD Open Access I Academic Resources / Scientific Indexing Services / SCIPIO I JIFACTOR

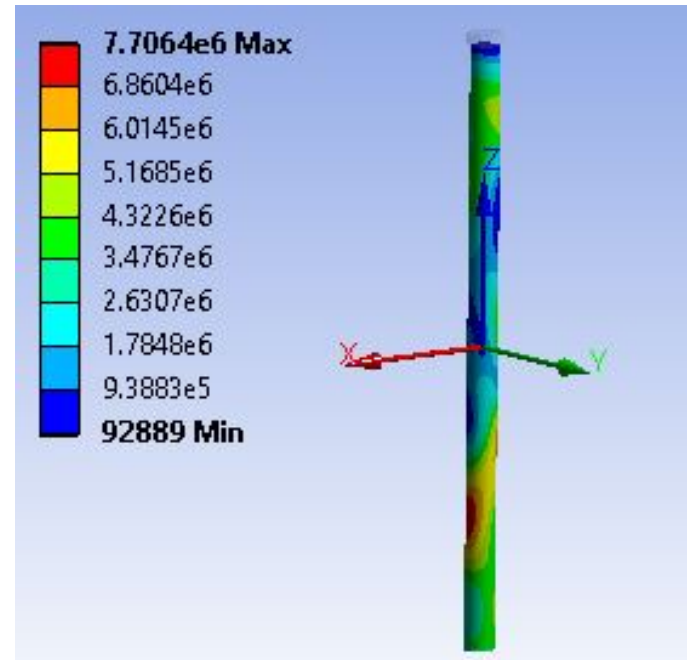

Figure 41 Von Misses stress diagram for step 71

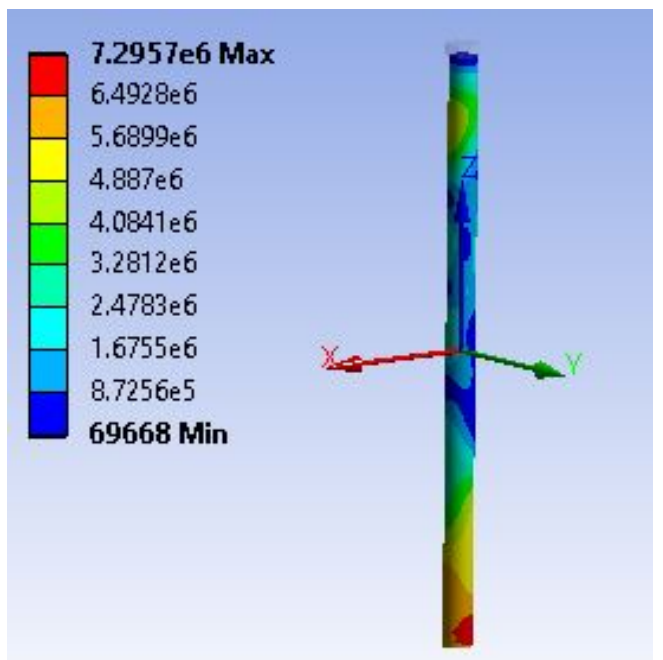

Figure 42 Von Misses stress diagram for step 73

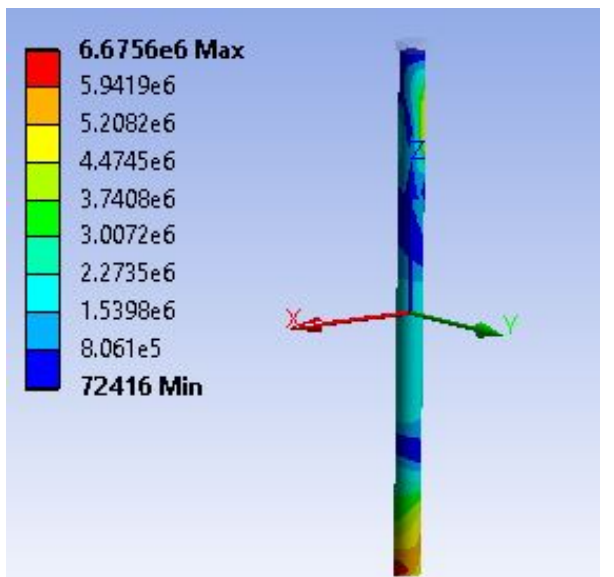

Figure 43 Von Misses stress diagram for step 75

DOI: 10.21279/1454-864X-16-12-036

(c) 2015. This work is licensed under the Creative Commons Attribution-Noncommercial-Share Alike 4.0 License.

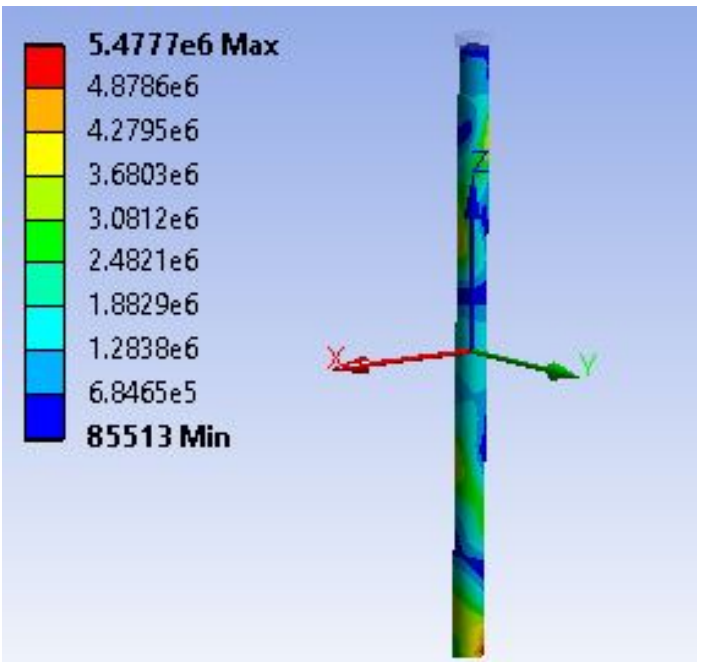

Figure 44 Von Misses stress diagram for step 77

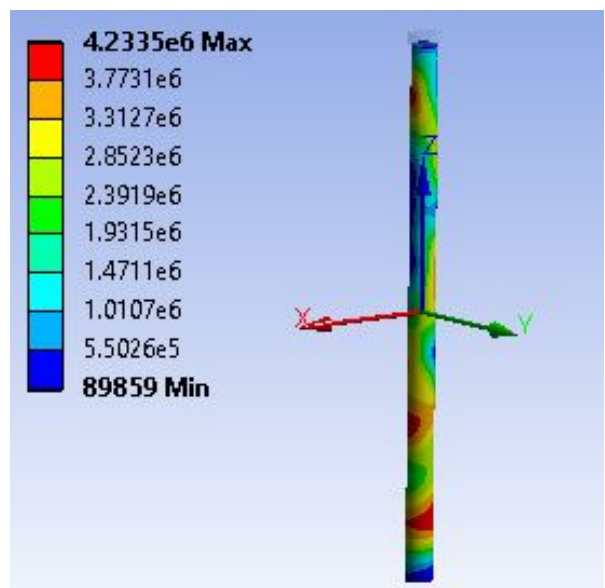

Figure 45 Von Misses stress diagram for step 79

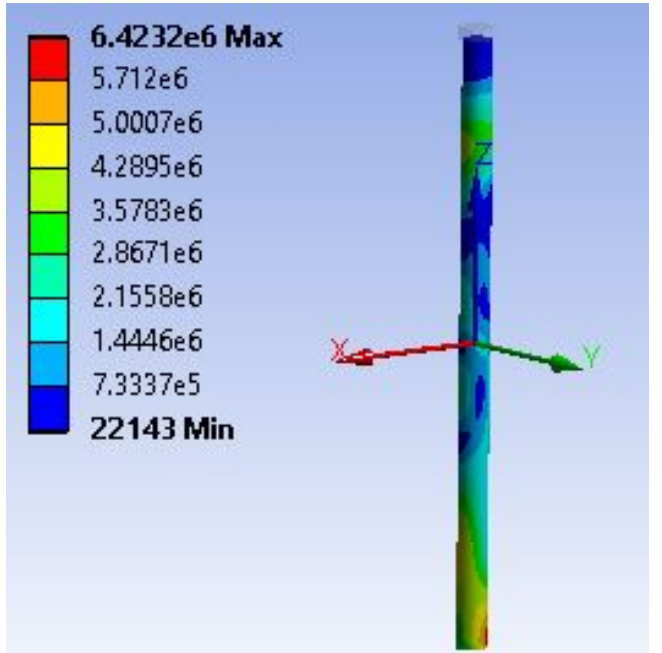

Figure 46 Von Misses stress diagram for step 81 
"Mircea cel Batran" Naval Academy Scientific Bulletin, Volume XIX - 2016 - Issue 2 The journal is indexed in: PROQUEST / DOAJ / Crossref / EBSCOhost / INDEX COPERNICUS / DRJI / OAJI / JOURNAL INDEX / I2OR / SCIENCE LIBRARY INDEX / Google Scholar / Academic Keys/ ROAD Open Access I Academic Resources / Scientific Indexing Services / SCIPIO / JIFACTOR

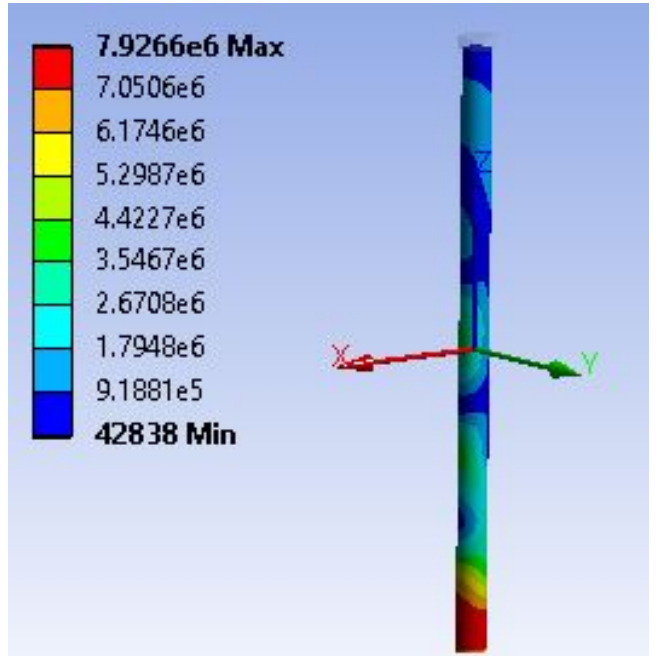

Figure 47 Von Misses stress diagram for step 83

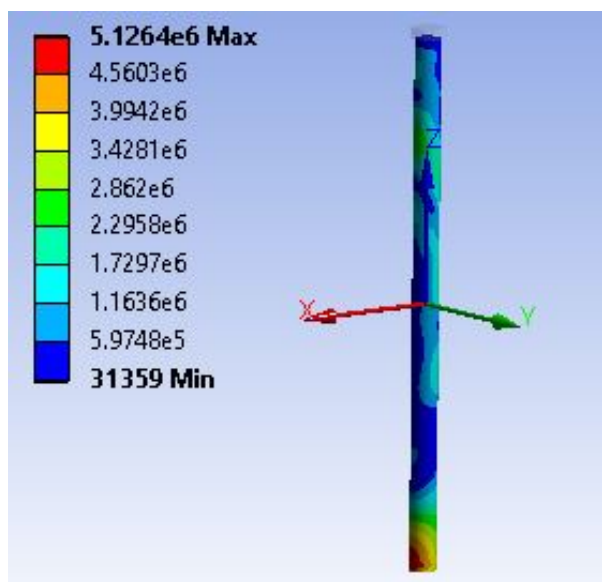

Figure 48 Von Misses stress diagram for step 85

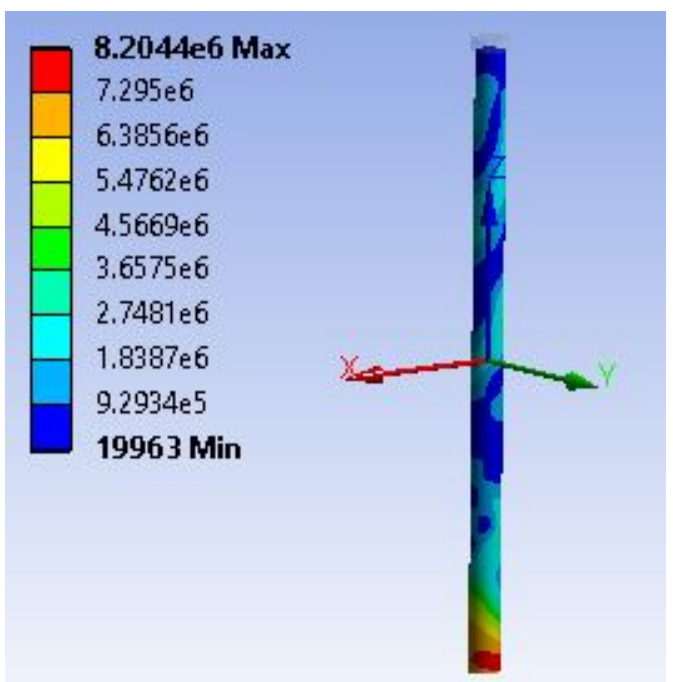

Figure 49 Von Misses stress diagram for step 87

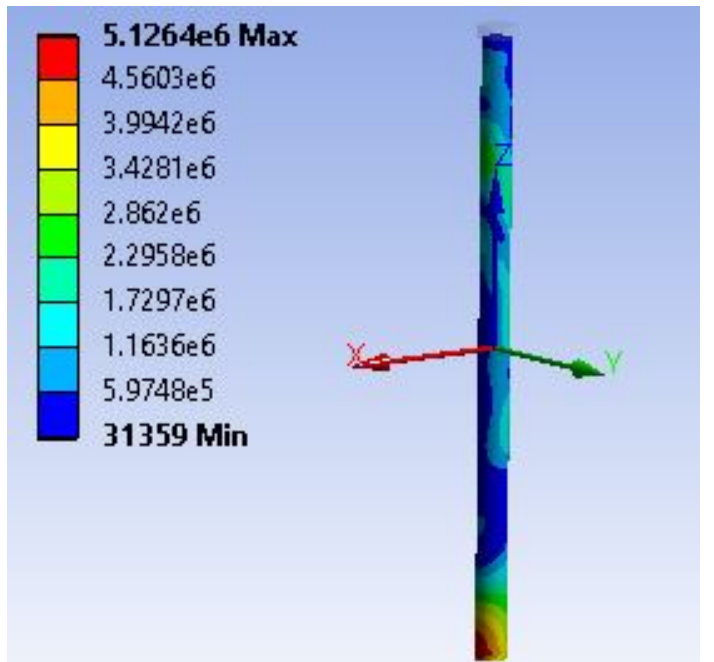

Figure 50 Von Misses stress diagram for step 89

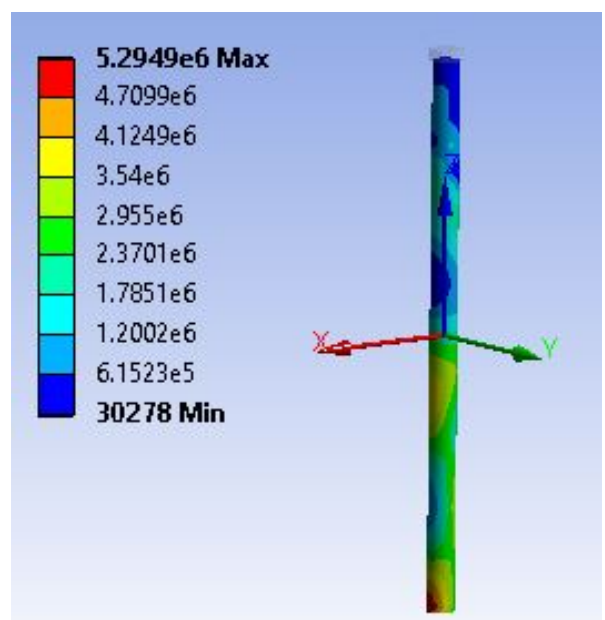

Figure 51 Von Misses stress diagram for step 91

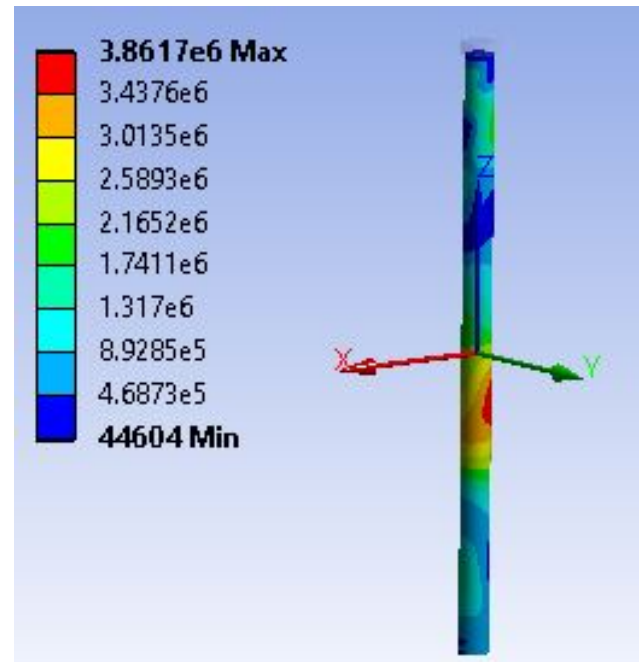

Figure 52 Von Misses stress diagram for step 93 
"Mircea cel Batran" Naval Academy Scientific Bulletin, Volume XIX - 2016 - Issue 2 The journal is indexed in: PROQUEST I DOAJ / Crossref / EBSCOhost / INDEX COPERNICUS / DRJI / OAJI / JOURNAL INDEX / I2OR / SCIENCE LIBRARY INDEX / Google Scholar / Academic Keys/ ROAD Open Access I Academic Resources / Scientific Indexing Services / SCIPIO / JIFACTOR

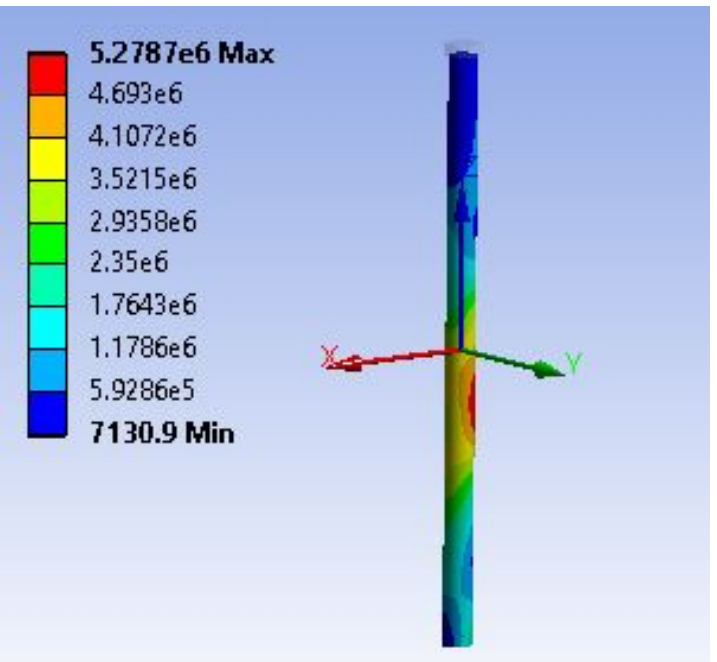

Figure 53 Von Misses stress diagram for step 95

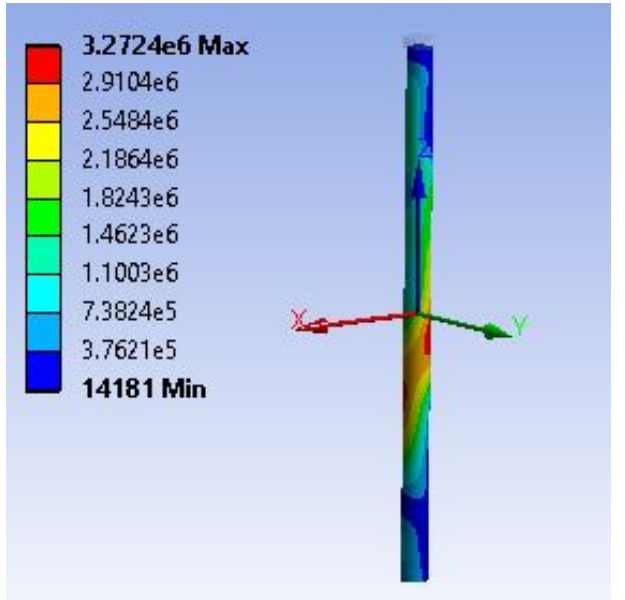

Figure 54 Von Misses stress diagram for step 97

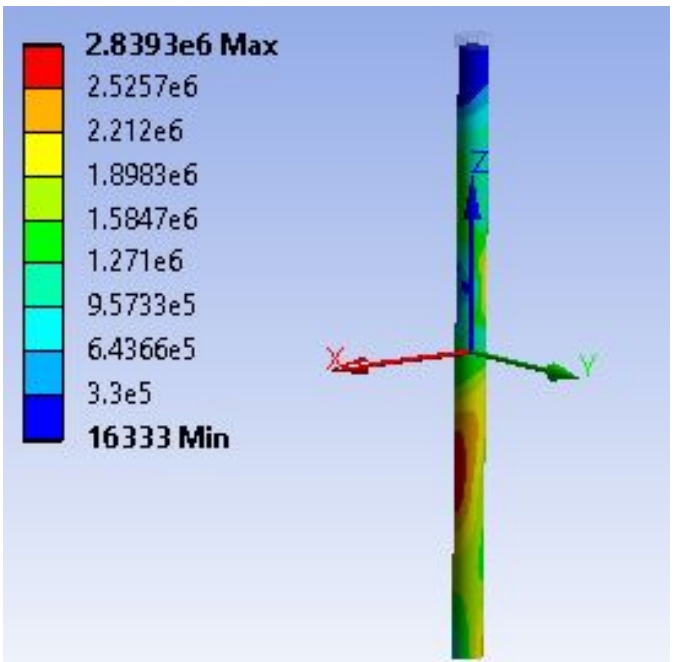

Figure 55 Von Misses stress diagram for step 99

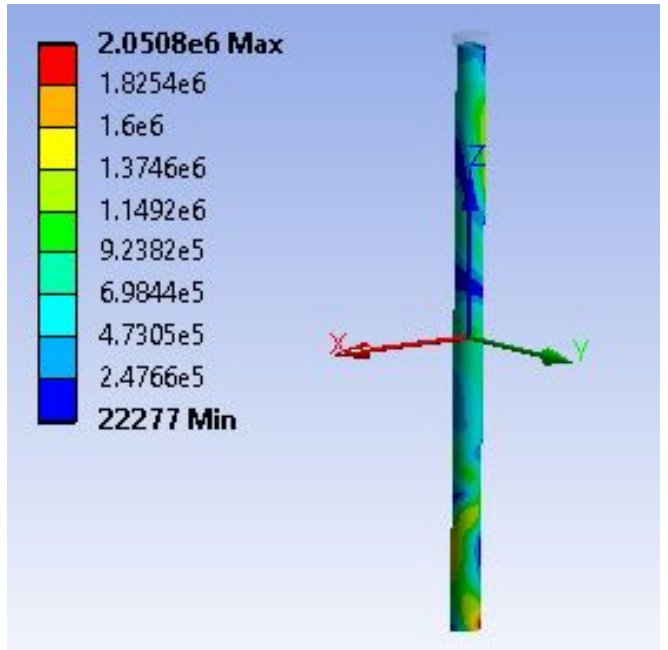

Figure 56 Von Misses stress diagram for step 101

\section{CONCLUSIONS}

The maximum value for the von Misses stress is reached at step 2 (0.01 seconds) and the value is 77.863 $\left[\mathrm{N} / \mathrm{mm}^{2}\right]$.

\section{BIBLIOGRAPHY}

[1] www.ansys.com

[2] www.vulcanhammer.info 